\title{
Catalytic fuel cell used as an analytical tool for methanol and ethanol determination. Application to ethanol determination in alcoholic beverages
}

\author{
Mauro Tomassetti*, Riccardo Angeloni, Giovanni Merola, Mauro Castrucci, \\ Luigi Campanella \\ Department of Chemistry, University of Rome, “La Sapienza”, P.le A. Moro 5, 00185, Rome, Italy
}

\section{A R T I C L E I N F O}

\section{Article history:}

Received 28 October 2015

Accepted 25 December 2015

Available online 14 January 2016

\section{Keywords:}

Fuel cell

methanol

ethanol

wines and beers

analysis

\begin{abstract}
A B S T R A C T
A small direct catalytic methanol 'fuel cell' was used for analytical purposes. Three different formats were investigated for methanol and ethanol determination: two different Open Circuit Voltage (OCV) formats and a potentiostatic (i.e. amperometric) format; the latter was used if the current supplied by the cell was recorded. The measurement times using one or other of these three formats were much different. The time required by the potentiostatic format was more short for a suitable analytical measurement. The cell was used to check ethanol content in several commercial wine and beer samples and the possibility of using the fuel cell for the analytical measures in real samples, discussed. Lastly the results were compared with those obtained using two conventional amperometric enzyme sensors and statistical tests carried out.
\end{abstract}

(c) 2016 Elsevier Ltd. All rights reserved.

\section{Introduction}

As is well known, fuel cells are devices capable of converting chemical energy into electric power. In recent decades these devices, at least theoretically non polluting, have attracted much attention [1-5] owing to high electric power demands and the strong increase in environmental pollution due to the intensive combustion of fossil fuels for electrical energy production. The most frequently used and tested type of fuel cell is without doubt the " Proton Exchange Membrane Fuel Cell" (PEMFC), although numerous studies have focused also on the "Direct Methanol Fuel Cell" (DMFC), the "Phosphoric Acid Fuel Cell" (PAFC), the "Solid Oxide Fuel Cell" (SOFC), the "Alkaline Fuel Cell" (AFC) and so on $[6,7]$. The fuel cells currently considered as highly efficient are without doubt those using dihydrogen and dioxygen gas as fuel $[8,9]$. The disadvantage of this type of fuel cell is the high cost of hydrogen production, but especially the need for safety engineering governing the use, storage and transport of hydrogen. An attractive alternative to using hydrogen as fuel is to use methanol (or ethanol) as anodic fuel. This entails the use of a renewable and already widely available and relatively cheap product that is easy to store and transport. For this reason a considerable number of

\footnotetext{
* Corresponding author.

E-mail address: mauro.tomassetti@uniroma1.it (M. Tomassetti).
}

studies have focused on the use of methanol in fuel cells [10-14]. The result was the development of "Direct Methanol Fuel Cells" (DMFCs), the reactions underlying the functioning of which are well known:

$$
\mathrm{CH}_{3} \mathrm{OH}+\mathrm{H}_{2} \mathrm{O} \rightarrow \mathrm{CO}_{2}+6 \mathrm{H}^{+}+6 e^{-} \quad \text { anodic reaction }
$$
$3 / 2 \mathrm{O}_{2}+6 \mathrm{H}^{+}+6 e^{-} \rightarrow 3 \mathrm{H}_{2} \mathrm{O}$
cathodic reaction

Furthermore, ethanol represents an interesting alternative fuel for these devices [15]. However, direct ethanol fuel cells (DEFCs) have a lower performance than DMFCs due to the high over potential for the electrochemical oxidation of the ethanol at low temperatures [15], nevertheless, the energy density of ethanol is greater than that of methanol if complete oxidation to $\mathrm{CO}_{2}$ is achieved [15]. In addition ethanol and its oxidation products (acetaldehyde and acetic acid) are less toxic than methanol and its oxidation products. Lastly, the ethanol deriving from biomass fermentation is now widely produced in numerous countries in the form of a relatively cheap vehicle fuel. Therefore the use of ethanol to power fuel cells has also been taken into consideration [15]. Of course, practically all the studies performed on direct methanol or ethanol fuel cells refer to: the power performance, the engineering and the electrochemical reactions underlying their performance and their possible use as devices capable of converting chemical energy into electrical energy. However, recently, a relatively small 
number of publications have described also the possible use of DMFCs as electrochemical sensors for methanol [16-18], in some cases proposing quite sophisticated devices, for example, cells constructed with two anodes face to face [19], or bioelectrochemical fuel cell enzyme sensors [20]. Nevertheless, these works deal essentially, as we have seen, with the development of original, and often very interesting, devices [16,17], or else provide a detailed description of the various operating modes [21], rather than evaluate the real potential of simple and thus cheap DMFCs to be used for essentially analytical purposes and their effective application in the analysis of real matrixes, or even for the comparison with other types of electroenzymatic sensors already widely used in the field of methanol or ethanol analysis. Therefore, in recent years our research group has developed different sensors for ethanol (and methanol) determination using biosensors working in aqueous [22] or organic solvent [23]. Our team have now investigated the feasibility of using a small commercial direct catalytic methanol 'fuel cell', originally constructed for the purpose of obtaining energy from methanol or ethanol, for analytical purposes. The aim was to see whether this kind of device could effectively be used for ethanol and methanol determination in real samples. Once the device had been developed and characterized electroanalytically, the ethanol content was determined in several commercial samples of wine and beer. The data thus obtained were compared with those obtained by carrying out the analysis of the same samples using two different enzymatic biosensors recently tested by us [22].

\section{2. experimental}

\subsection{Materials}

The standard solutions used for the fuel cell measurement were obtained by diluting with distilled water known volumes of methanol (CAS: 67-56-1) 99.8\% purity, ethanol (CAS: 64-17-5) $\geq 99.8 \%$ purity, propanol (CAS: 71-23-8), n-butanol (CAS: 71-36-3), isoamyl alcohol (CAS: 123-51-3), tert-butanol (CAS: 75-65-0), isopropanol (CAS: 67-63-0), sec-butanol (CAS: 78-92-2), ethylene glycol (CAS:107-21-1) and glycerol (CAS:56-81-5). All the latter, 99.5\% pure, were supplied by Sigma Aldrich (Milan, Italy). To construct the two different conventional amperometic enzyme biosensors, the following enzymes were used: respectively catalase (E. C. 1.11.1.6) from bovine liver (2110 units/mg solid) and alcohol oxidase (E.C. 1.1.3.13) from Candida bodinii (1.16 units/ mg solid), both supplied by Sigma Aldrich (Milan, Italy). The gel used for the physical immobilization of both enzymes was obtained using K-carrageenan RPE from Fluka (Bucks, Switzerland). The standard hydrogen peroxide solution was obtained by diluting hydrogen peroxide (CAS:7722-84-1) 40\% m/ V Carlo Erba, RE (Milan, Italy) in distilled water. The anhydrous dibasic sodium phosphate (CAS: 7558-79-4), 99\% pure, and potassium chloride (CAS: 7447-40-7), $\geq 99.5 \%$ pure, used to prepare the buffer solutions, were supplied by Carlo Erba (Milan, Italy) and Fluka (Buchs, Switzerland), respectively.

\subsection{Samples}

Seven samples of commercial wine and beer were analyzed: two white and two red wines, and three samples of beer. Three wine samples were contained in sealed dark glass bottles purchased at the local market, while one was an artisanal product supplied by local producers (Lazio, North Rome). Three different beer samples were all commercial products contained in sealed bottles purchased at the local market. Before measurement, wine samples were diluted of about 125 times and beer samples of about

\section{METHANOL \\ or ETHANOL}

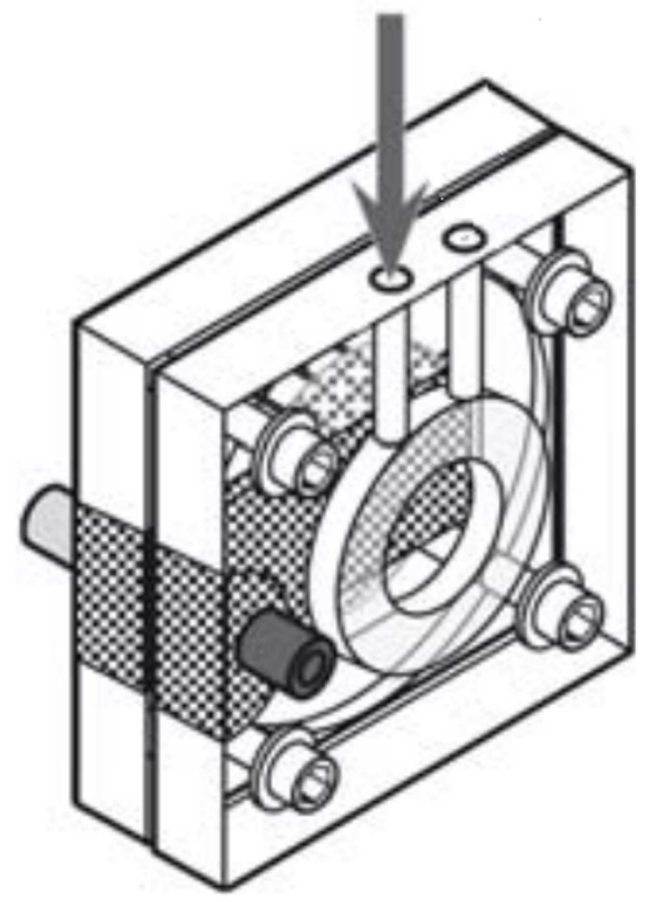

Fig. 1. H-Tec model F111 Direct Methanol Fuel Cell.

50 times, then about $2 \mathrm{~mL}$ of these diluted samples were directly introduced in the fuel cell.

\subsection{Fuel cell and measurement apparatus}

For the fuel cell measures a DMFC H-TEC Model F111 (Fig. 1), ( $50 \mathrm{~mm} \times 50 \mathrm{~mm} \times 40 \mathrm{~mm}$ ) weighing $100 \mathrm{~g}$ was obtained from Fuel Cell Store (College Station, TX, USA). The electrode area was about $4 \mathrm{~cm}^{2}$ and the maximum generated power $10 \mathrm{~mW}$. The Fuel Cell frame was made of Plexiglas ${ }^{\circledR}$, while the electrode end plate was made of a Pt-Ru black catalyst assembled with a Nafion ${ }^{\mathrm{TM}}$ membrane. For OCV format and OCV kinetic format measurements the fuel cell was connected to an Agilent/HP 34401A digital multimeter with $1 \mathrm{G} \Omega$ input-impedance and the data collected through a PC interface using HP IntuiLink software. For potentiostatic format measurement a Palmsens mod. EmStat general purpose potentiostat was used, connected to a fuel cell. The current supplied to the cell was recorded and stored using a PSTrace Software ver. 4.6 data interface on a Compaq Presario PC.

\subsection{Conventional amperometric biosensor measurement apparatus.}

For the amperometric biosensor measures a model $3001 \mathrm{ABD}$ Biosensor Amperometric Detector potentiostat was used, together with a model 4000-1 amperometric electrode for oxygen measurement, both supplied by Universal Sensor Inc. (New Orleans USA); the measures were carried out under moderate constant stirring using a magnetic stirrer in a $50 \mathrm{~mL}$ glass cell thermostated at $23^{\circ} \mathrm{C}$ [77-79]; the signal was recorded on a model 868 Amel analog recorder (Milan, Italy). 


\subsection{Measurements using two different conventional enzymatic- amperometric biosensors}

Measurements by two conventional enzymatic-amperometric biosensors were carried out using two different formats. The two devices, previously developed and standardized [22], were assembled by coupling an amperometric gas-diffusion oxygen electrode (Clark Type) and catalase or alcohol oxidase enzyme immobilized in k-Carrageenan gel overlapping the head of the amperometric electrochemical sensor. A detailed description of these biosensors assemblies was given in a previous paper [22]. In the case of the catalase enzyme electrode, the measurement was performed by adding hydrogen peroxide to a buffer solution so that at the enzymatic layer the following reaction catalysed by the catalase enzyme took place:

$\mathrm{H}_{2} \mathrm{O}_{2} \stackrel{\text { catalase }}{\longrightarrow} \frac{1}{2} \mathrm{O}_{2}+\mathrm{H}_{2} \mathrm{O}$

Since this reaction led to the production of oxygen, the concentration of the latter in the measurement solution increased. This increase triggered an increase in the cathodic current measured which increased from the original value to a new stationary state. At this stage further additions were made (equal to $20 \mu \mathrm{L}$ ) of a standard solution of $0.008 \mathrm{M}$ of ethanol; After each addition a reaction of the following type occurred which was again catalyzed by catalase:

$\mathrm{CH}_{3} \mathrm{CH}_{2} \mathrm{OH}+\mathrm{H}_{2} \mathrm{O}_{2} \stackrel{\text { catalase }}{\longrightarrow} \mathrm{CH}_{3} \mathrm{CHO}+2 \mathrm{H}_{2} \mathrm{O}$

The second reaction removed part of the $\mathrm{H}_{2} \mathrm{O}_{2}$ substrate from the first reaction, which was slowed down; this slowdown was accompanied by a decrease in the level of oxygen produced in the solution during the first reaction; this decrease was evidenced by the decrease in the measured cathodic current which attained a new stationary state after each addition of alcohol solution. Each current variation was read off after each alcohol addition and used to construct a calibration curve.

With the biosensor operating with alcohol oxidase the operating procedure was much simpler as it consisted of directly making successive additions of the standard ethanol solution to a buffer solution in which the measurement was being performed. After each addition a reaction catalyzed by the alcohol oxidase enzyme of the following type took place:

$\mathrm{CH}_{3} \mathrm{CH}_{2} \mathrm{OH}+\mathrm{O}_{2} \stackrel{\text { alcohol oxidase }}{\longrightarrow} \mathrm{CH}_{3} \mathrm{CHO}+2 \mathrm{H}_{2} \mathrm{O}_{2}$

The reaction led to the oxygen present in the solution being consumed with a consequent decrease in the cathodic current measured until a new stationary state was reached. Also in this case, after each addition, the current variation was read off and a calibration curve constructed. All the experiments were carried out in a reaction cell thermostated at $23^{\circ} \mathrm{C}$ containing $15 \mathrm{~mL}$ of $0.05 \mathrm{M}$ phosphate buffer solution. In all cases the variation of the oxygen concentration in the aqueous solution due to the enzymatic reactions was measured at a constant applied potential of $-650 \mathrm{mV}$. Further details concerning these two biosensor methods were all explained in previous published paper [22].

\section{Fuel cell measurement and calibration curves}

Fuel cell potential measurements, in OCV format [21,24], were carried out using a Digital Multimeter HP 34401A, connected to fuel cell which allowed measurement with high input impedance (about $10 \mathrm{G} \Omega$ ). The data recorded by the multimeter were sent through a data interface to the Compaq Presario PC with HP IntuiLink software.

Conversely the alternative amperometric format $[16,19,21]$ was to recording the supplied current (SC) by the cell i.e. working in potentiostatic format mode; in this case the potentiostat Palmsens mod. EmStat was used, connected to the PC running PSTrace ver. 4.6. software for data acquisition and processing. The fuel cell anode was connected as working electrode to EmStat, while the fuel cell cathode was connected to an EmStat reference and counter electrode. Before current measurement the EmStat automatically measured every time OCV value for about $200 \mathrm{sec}$ onds, then set the anode potential to a value of $100 \mathrm{mV}$ lower than the measured OCV value (OCV minus $100 \mathrm{mV}$ ), the supplied current was recorded and, after the steady-state was reached, the current value was checked. In both cases, before measuring, the fuel cell was carefully washed with $0.5 \%$ water-methanol (or ethanol) solution and then several times with distilled water. Subsequently for a next measurement the fuel cell was filled with the solution to be analyzed (approximately $2 \mathrm{~mL}$ ) and closed to prevent evaporation of the alcohol. Measurement could begin after conditioning the system for about 60 seconds.

This second amperometric measurement format $[16,19,21]$ was similar to the galvanostatic format, reported in the literature by other authors [19,21,25]; In fact the results obtained were practically the same in both cases, as we could verify experimentally, but this potentiostatic format was most simple and could be used also even if the potentiostat employed does not reached a high current full scale.

In the first experiments carried out, water-alcohol solutions containing increasing percentages of methanol or ethanol were progressively added to the cell at open circuit voltage (OCV) [21]

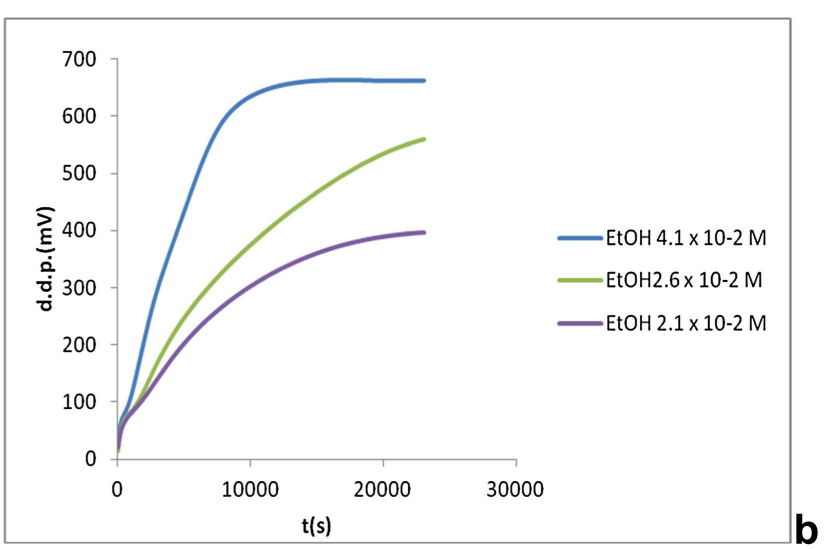

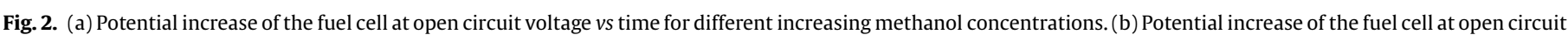
voltage vs time for different increasing ethanol concentrations. 

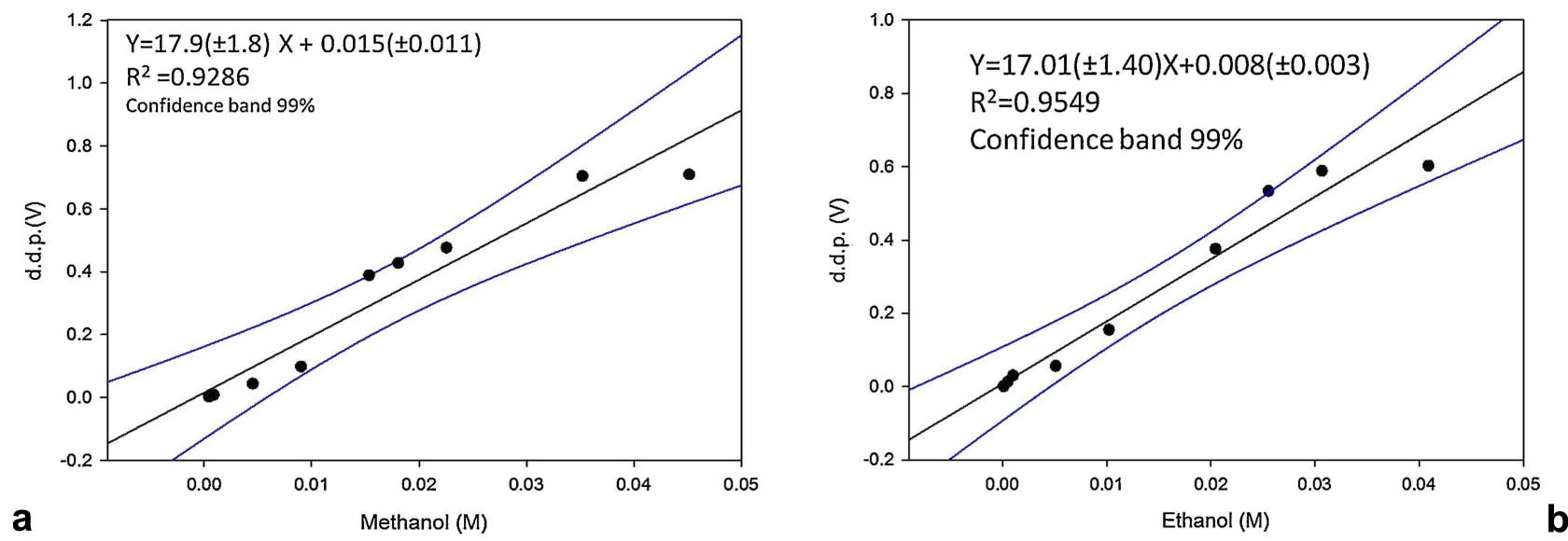

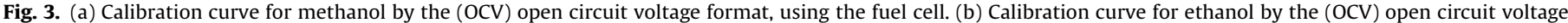
format, using the fuel cell.

and the increase in potential (which occurs between two electrodes of the cell) was recorded (Fig. 2(a) and (b)). The maximum potential obtained after each alcohol addition was so read off. We thus experimentally demonstrated that it was possible to obtain a calibration curve and its relative equations for methanol (see Fig. 3(a)), but also for ethanol (Fig. 3(b)), working in OCV format. Lastly, analogous calibration curves were obtained in OCV mode, but using the "kinetic format", i.e. taking the slope value of the initial trend of recorded OCV curves for methanol or ethanol (see the calibration curves in Fig. 4(a) and (b), together with the corresponding equations of calibration curves and correlation coefficient values, both reported in the latter figures). The main analytical data referring to the straight lines obtained by taking the maximum measurement voltage for each alcohol concentration (i.e. working at OCV format), or the initial slope data values of curve in Figs. 2(a) or 2(b) (i.e. working at OCV kinetic format), are all reported in Table 1.

The second research step was to repeat the above tests but this time using the potentiostatic format.

First of all however, to check the Optimized Applied Potential (OAP), the supplied current (SC) by the cell $[18,19,21]$ for one fixed alcohol concentration at different applied potentials between the electrodes was recorded (see Fig. 5(a) and (b)). From the trend of curves in the latter figures, the $\mathrm{OAP}=\mathrm{OCV}-100 \mathrm{mV}$ was decided to check as the best.

After optimizing the applied potential, operating at a fixed concentration of methanol or ethanol, measures were performed at different concentrations of ethanol or methanol, operating at $\mathrm{OAP}$, recording the current supplied after $55 \mathrm{~min}$ when it had reached a stationary state value (Fig. 6(a) and (b)). The current variations thus obtained have been reported as a function of the increasing concentration of the alcohol tested (see the calibration straight lines for methanol and ethanol in Fig. 7(a) and (b) respectively).

In the same figures, straight-line equations and $\mathrm{R}^{2}$ values are also reported, while the main analytical data of the calibration curves for methanol and ethanol thus obtained have also been summarized in Table 1.

\section{Results}

By representing the voltage drop across the external load expressed as a function of the current through that load, the socalled polarization curve may be obtained, which has traditionally characterized the performance of a fuel cell; this curve is actually helpful in explaining the chemistry and physics associated with fuel cell operation [26,27]. Fig. 8 shows the polarization curves obtained for methanol and ethanol in the fuel cell used. The activation region and the ohmic polarization region are quite apparent, while the available recording equipment did not allow the mass transfer limited region to be adequately highlighted. Fig. 9 shows the socalled power performance curves for both methanol and ethanol. These can be obtained immediately from the product ( $\mathrm{i} \times \mathrm{V}$ ) [26], i.e. the product of the steady state current
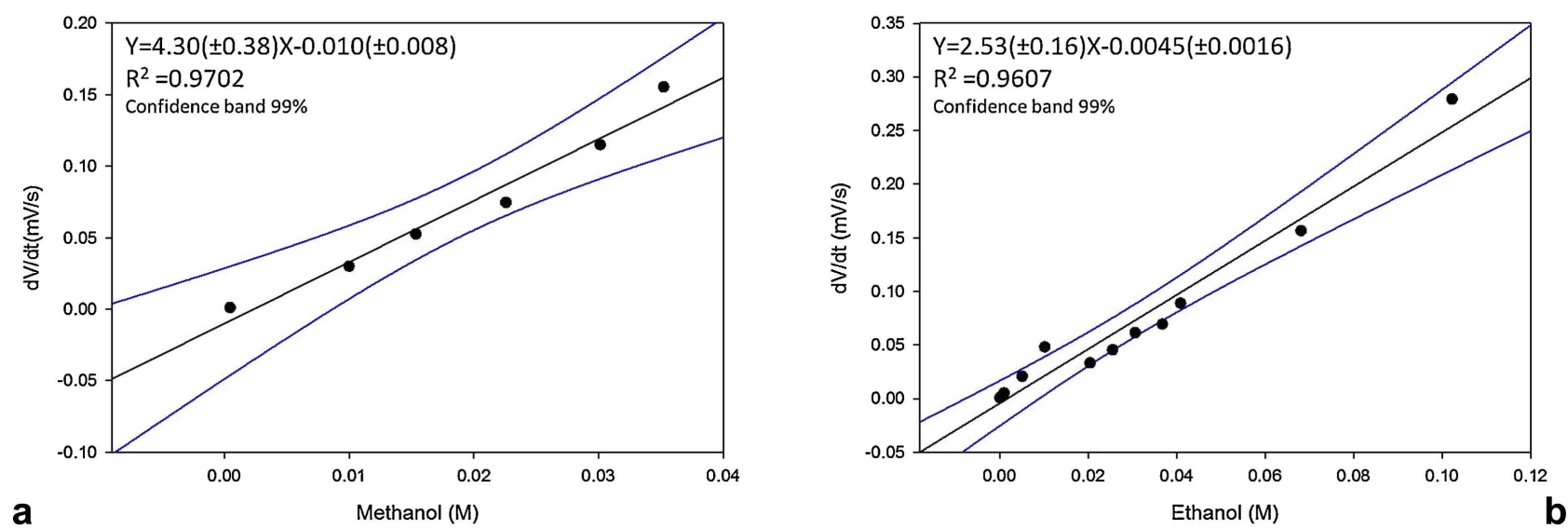

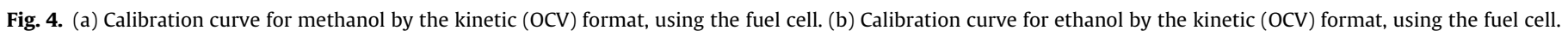


Table 1

Main Analytical Data.

\begin{tabular}{|c|c|c|c|c|c|c|c|}
\hline \multirow[t]{2}{*}{ Method } & \multicolumn{2}{|l|}{$\begin{array}{l}\text { Linearity range } \\
\text { Slope value } \\
\text { Correlation Coefficent } \\
\text { Pooled SD\% }\end{array}$} & \multicolumn{2}{|l|}{ LOD (M) } & \multicolumn{2}{|c|}{ Time of measurement } & \multirow[t]{2}{*}{ Life-time } \\
\hline & Methanol & Ethanol & Methanol & Ethanol & Methanol & Ethanol & \\
\hline Fuel cell OCV format & $\begin{array}{l}\left(4.5 \times 10^{-4}-4.5 \times 10^{-2}\right)(\mathrm{M}) \\
17.9( \pm 1.8) \\
\mathrm{R}^{2}=0.9286 \\
\text { Pooled } \mathrm{SD} \%=4.5\end{array}$ & $\begin{array}{l}\left(1.0 \times 10^{-4}-1.0 \times 10^{-2}\right)(\mathrm{M}) \\
17.01( \pm 1.4) \\
\mathrm{R}^{2}=0.9491 \\
\text { Pooled SD\% }=3.3\end{array}$ & $4.0 \times 10^{-4}$ & $0.5 \times 10^{-4}$ & $5-6 h$ & $5-6 h$ & $>3$ months \\
\hline Fuel cell OCV kinetic format & $\begin{array}{l}\left(4.5 \times 10^{-4}-3.5 \times 10^{-2}\right)(\mathrm{M}) \\
4.30( \pm 0.38) \\
\mathrm{R}^{2}=0.9702 \\
\text { Pooled SD\% }=7.5\end{array}$ & $\begin{array}{l}\left(1.0 \times 10^{-4}-1.0 \times 10^{-1}\right)(\mathrm{M}) \\
2.53( \pm 0.16) \\
\mathrm{R}^{2}=0.9607 \\
\text { Pooled SD\% }=6.7\end{array}$ & $4.0 \times 10^{-4}$ & $0.5 \times 10^{-4}$ & $\sim 65 \mathrm{~min}$ & $\sim 65 \mathrm{~min}$ & $>3$ months \\
\hline Fuel cell SC potentiostatic format at (OAP) & $\begin{array}{l}\left(1.0 \times 10^{-3}-2.0 \times 10^{-1}\right) \\
21.8( \pm 0.78) \\
\mathrm{R}^{2}=0.9912 \\
\text { Pooled SD\% }=7.2\end{array}$ & $\begin{array}{l}\left(1.0 \times 10^{-3}-4.0 \times 10^{-2}\right) \\
17.8( \pm 0.95) \\
\mathrm{R}^{2}=0.9888 \\
\text { Pooled SD\% }=6.8\end{array}$ & $8.0 \times 10^{-4}$ & $8.0 \times 10^{-4}$ & $\sim 55 \mathrm{~min}$ & $\sim 55 \mathrm{~min}$ & $>3$ months \\
\hline
\end{tabular}
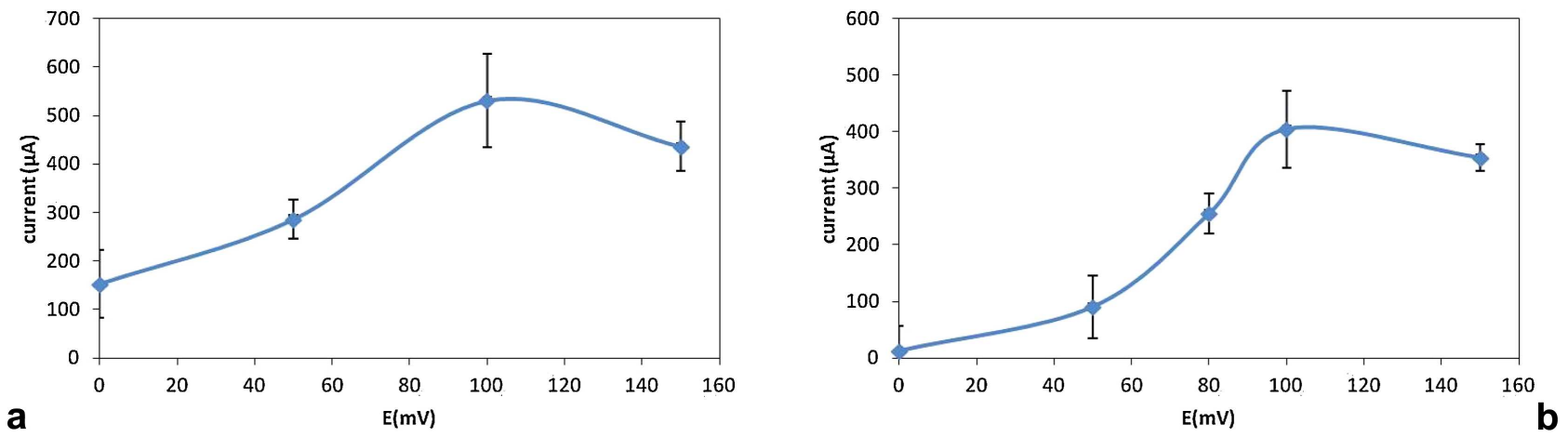

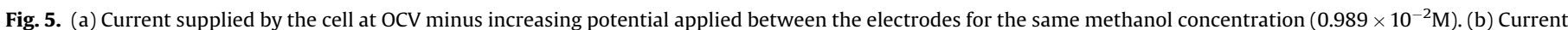
supplied by the cell at OCV minus increasing potential applied between the electrodes for the same ethanol concentration $\left(1.081 \times 10^{-2} \mathrm{M}\right)$.
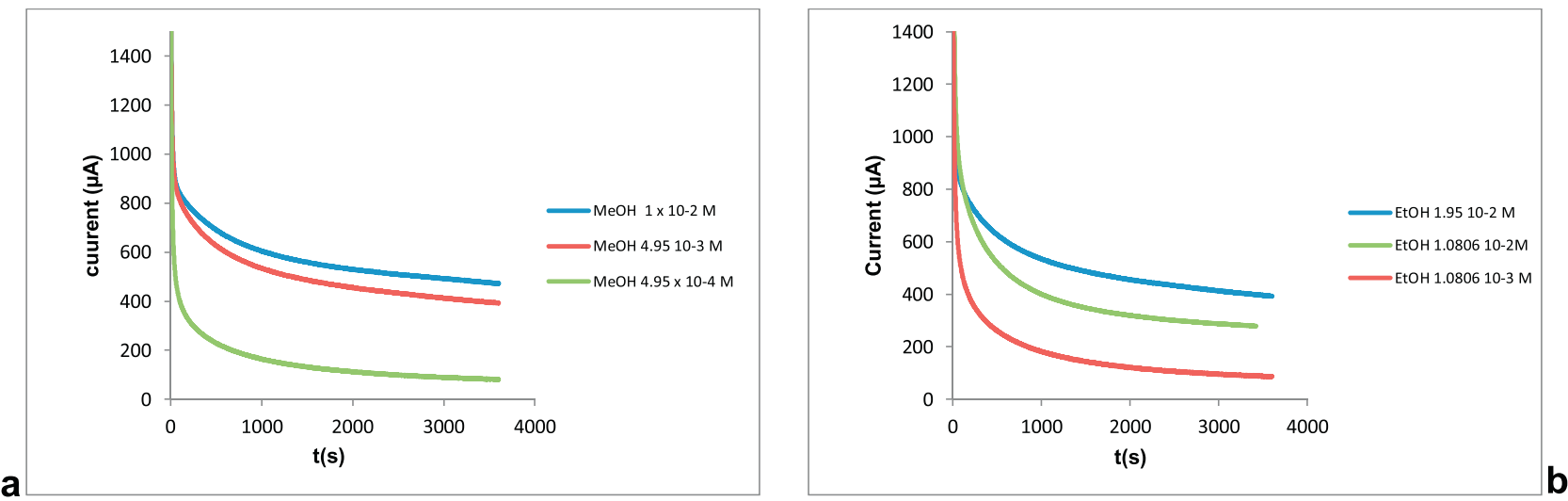

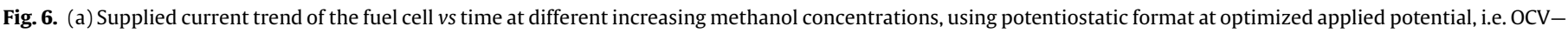

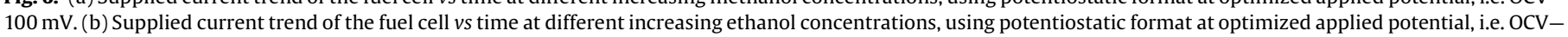
$100 \mathrm{mV}$.

through the external loads and voltage drop across the external load. It can be seen how the power curve of the ethanol is always lower than that of methanol obtained under the same experimental conditions. This is in agreement with the values of the sensitivity of calibration of the above-mentioned calibration straight lines: Moreover, the maximum power obtained (1.5 mW) using methanol $\left(\approx 10^{-2} \mathrm{M}\right)$ is seen to be of the same order of magnitude as the maximum value declared by the cell manufacturer for a methanol concentration of $(\approx 0.1-1 \mathrm{M})$.

In Table 2, selectivity data of fuel cell referring to several other alcohols tested are shown and compared with selectivity data found for other two enzymatic biosensors. The latter are more selective. Table 3 contains a comparison of main analytical data obtained using the fuel cell and two different previously developed conventional biosensor methods [22]. 

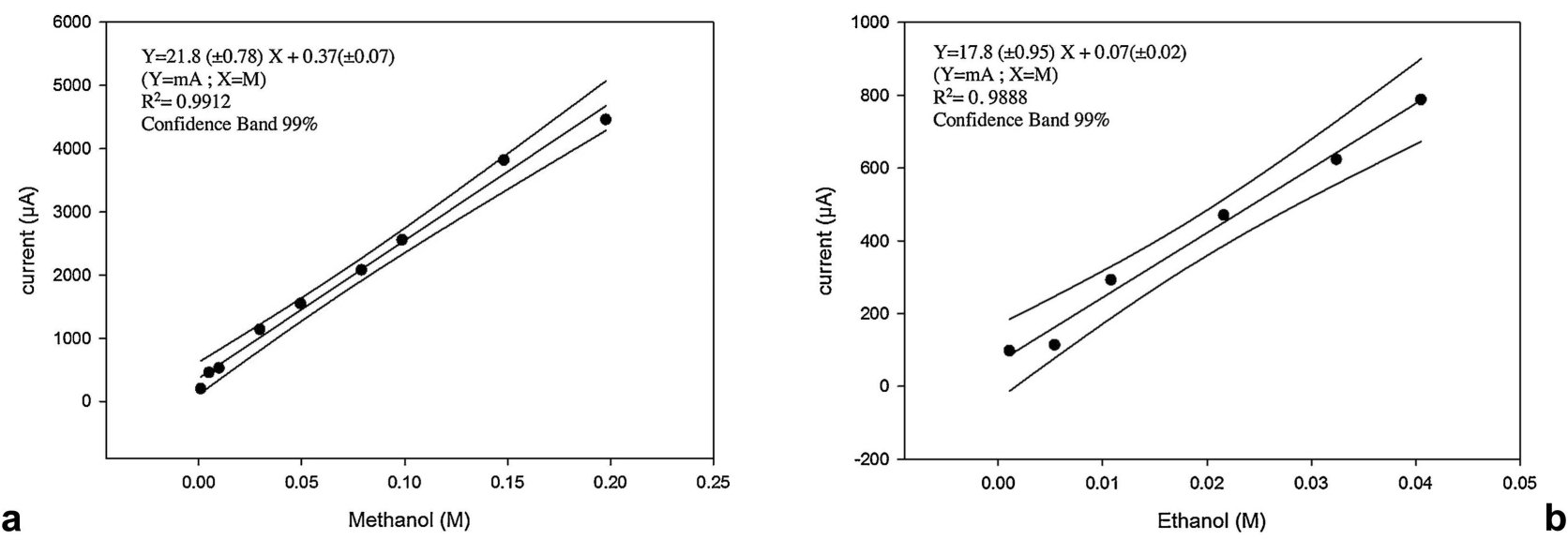

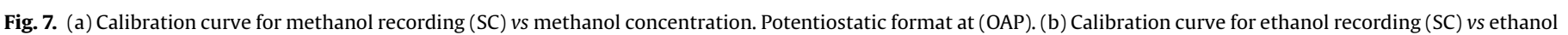
concentration. Potentiostatic format at (OAP).

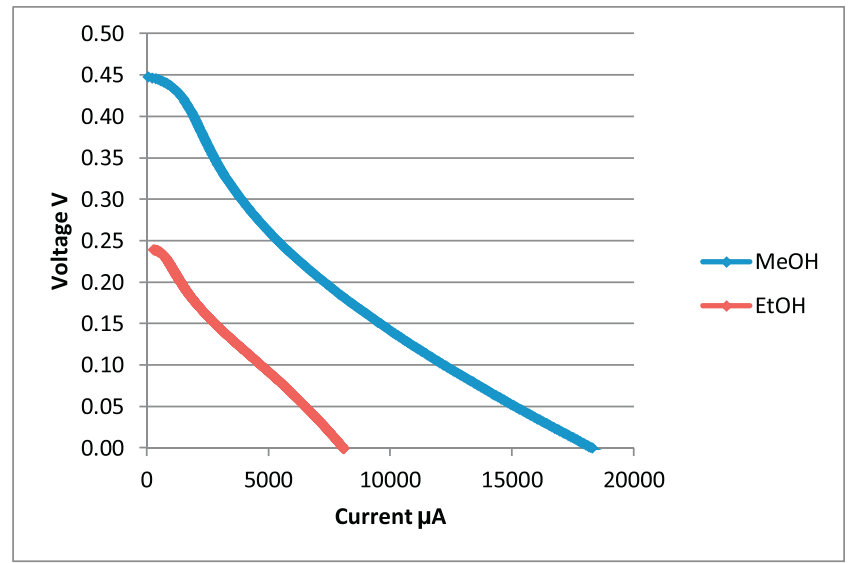

Fig. 8. Characteristic polarization curves of DMFC for Methanol and Ethanol (0.02 M).

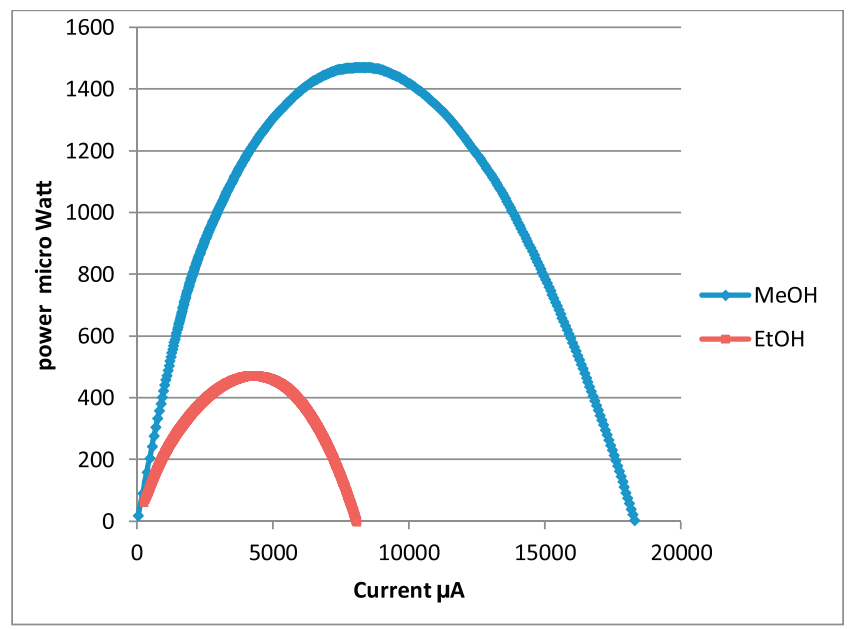

Fig. 9. Characteristic "power curves" of DMFC for Methanol and Ethanol (0.02 M).

Table 4 shows a comparison of results obtained using the fuel cell and two different conventional biosensor methods for ethanol analysis of several alcoholic beverages, while in Tables 5 and 6 statistical tests, applied to Table 4 data are displayed. Lastly, in
Table 7 the correlation of straight line equations among three methods are shown.

\section{Discussion}

It must be pointed out in the first instance that, unlike several literature reports regarding DMFC devices, our measures were carried out not in a flow mode and above all at temperature higher than room temperature (however not exceeding $60^{\circ} \mathrm{C}$, as was the case for the majority of other authors working in this field [16-21]). Our decision was not made by chance as the intention was to explore the possibility of making measurements of ethanol or methanol as simply as possible using highly compact instruments in order to perform measures at room temperature. It is clear, however, that despite not being operated in strictly thermostated mode, all the measurements were performed in the same laboratory, equipped with an efficient air conditioning system; practically the ambient temperature is not varied by more or less one degree ${ }^{\circ} \mathrm{C}$ during the whole period of time in which the measurements were made. This in practice prevented that results was affected significantly by the effect of temperature that for these sluggish anodic reaction could be generally not negligible $[10,12]$.

A comparison of the linearity range values (see Table 1 ) shows that, when operating in OCV format, the linearity range is about two decades while, when operating in (SC) potentiostatic format, it is about 1.5-2 decades; the LOD is about half a decade lower when operating in OCV format. Nevertheless, the measurement time is much shorter when operating in OCV kinetic format, or in (SC) potentiostatic format (it is actually at least 5 times lower than when operating in OCV format). On the other hand account should be taken of the fact that, the shortness of the measurement time, it is not just important for practical purposes, but it is also crucial so that is minimized the possible effect of cross-over through the membrane of the fuel cell $[16,19]$. The cross-over in fact increases increasing of the alcohol concentration and the time of measurement; particularly for this reason the more favorable operating formats seem to be the kinetic format (operating in OCV), but above all the potentiostatic format, with which the measurement can be carried out over more short time, as experiences, previously described, they have shown. The effect of cross-over, that at the low concentrations appears to be negligible, at least in the case of the cell used by us (because the answer of fuel cell remains linear increasing the alcohol concentration), instead is certainly the main responsible for the loss of linearity, which starts to observe at more high alcohol concentrations (average of the order of $5 \times 10^{-2} \mathrm{M}$ ). 
Table 2

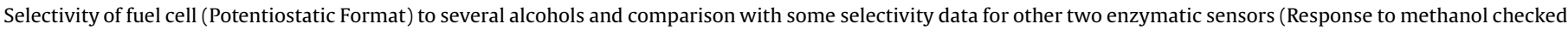
as $100 \%$ in the case of fuel cell and alcohol oxidase biosensor; response to ethanol checked as $100 \%$ in the case of catalase biosensor).

\begin{tabular}{|c|c|c|c|}
\hline Alcohol & $\begin{array}{l}\text { Fuel cell Response \% } \\
(\mathrm{SD} \% \leq 0.5)\end{array}$ & Alcohol Oxidase biosensor Response \% (SD\% $\leq 0.5$ ) & Catalase biosensor Response \% (SD\% $\leq 0.5)$ \\
\hline Methanol & 100.00 & 100.00 & No response \\
\hline Ethanol & 80.41 & 63.45 & 100.00 \\
\hline$n$-butanol & 63.00 & 18.72 & 17.30 \\
\hline tert-Butanol & 62.27 & No response & 1.20 \\
\hline Isopropanol & 55.49 & 8.20 & 15.00 \\
\hline Isobutanol & 43.40 & 4.92 & 6.50 \\
\hline$n$-propanol & 41.16 & 32.49 & 40.00 \\
\hline sec-butanol & 27.21 & No response & 2.70 \\
\hline
\end{tabular}

Table 3

Comparison of main analytical data of three sensors.

\begin{tabular}{|c|c|c|c|c|c|c|}
\hline \multirow[t]{2}{*}{ Method } & \multicolumn{2}{|l|}{ Linearity range } & \multicolumn{2}{|l|}{ LOD } & \multirow[t]{2}{*}{ Life time } & \multirow{2}{*}{$\begin{array}{l}\text { Analysis } \\
\text { time }\end{array}$} \\
\hline & Methanol & Ethanol & Methanol & Ethanol & & \\
\hline Catalase biosensor & $\left(9.5 \times 10^{-4}-2.1 \times 10^{-2}\right) \mathrm{M}$ & $\left(2.0 \times 10^{-6}-2.0 \times 10^{-5}\right) \mathrm{M}$ & $3.5 \times 10^{-4} \mathrm{M}$ & $0.4 \times 10^{-6} \mathrm{M}$ & $\approx 30$ days & $\approx 34 \mathrm{~min}$ \\
\hline Alcohol oxidase biosensor & $\left(8.2 \times 10^{-6}-3.7 \times 10^{-4}\right) \mathrm{M}$ & $\left(9.2 \times 10^{-6}-3.4 \times 10^{-4}\right) \mathrm{M}$ & $2.2 \times 10^{-6} \mathrm{M}$ & $3.6 \times 10^{-6} \mathrm{M}$ & $\approx 7$ days & $\approx 25 \mathrm{~min}$ \\
\hline Fuel cell OCV format & $\left(4.5 \times 10^{-4}-4.5 \times 10^{-2}\right) \mathrm{M}$ & $\left(1.0 \times 10^{-4}-1.0 \times 10^{-2}\right) \mathrm{M}$ & $4.0 \times 10^{-4} \mathrm{M}$ & $0.5 \times 10^{-4} \mathrm{M}$ & $>3$ months & $\begin{array}{l}\approx 5-6 \mathrm{~h} \\
(\approx 65 \mathrm{~min}) \text { kinetic format }\end{array}$ \\
\hline Fuel cell (SC) potentiostatic format at OAP & $\left(1.0 \times 10^{-3}-2.0 \times 10^{-1}\right) \mathrm{M}$ & $\left(1.0 \times 10^{-3}-4.0 \times 10^{-2}\right) \mathrm{M}$ & $8.0 \times 10^{-4} \mathrm{M}$ & $8.0 \times 10^{-4} \mathrm{M}$ & $>3$ months & $\approx 55 \mathrm{~min}$ \\
\hline
\end{tabular}

Table 4

Comparison of results obtained using the fuel cell and two different biosensor methods for ethanol analysis of several alcoholic beverages (beers and wines).

\begin{tabular}{|c|c|c|c|c|c|c|c|}
\hline \multirow[b]{2}{*}{ Samples } & \multirow[b]{2}{*}{$\begin{array}{l}\text { Nominal value of } \\
\text { Ethanol } \\
\text { Concentration }{ }^{1}(\% \\
\text { V/V) }\end{array}$} & \multicolumn{2}{|c|}{ Catalase Biosensor } & \multicolumn{2}{|c|}{ Alcohol Oxidase Biosensor } & \multicolumn{2}{|l|}{ Fuel cell } \\
\hline & & $\begin{array}{l}\text { Ethanol } \\
\text { concentration } \\
\text { found } \\
(\% \mathrm{~V} / \mathrm{V})\end{array}$ & $\begin{array}{l}\text { Ethanol } \\
\text { concentration } \\
\text { found } \\
(\mathrm{g} / \mathrm{L}) \\
\pm \mathrm{SD}(\mathrm{g} / \mathrm{L})\end{array}$ & $\begin{array}{l}\text { Ethanol } \\
\text { concentration } \\
\text { found } \\
(\% \mathrm{~V} / \mathrm{V})\end{array}$ & $\begin{array}{l}\text { Ethanol } \\
\text { concentration } \\
\text { found } \\
(\mathrm{g} / \mathrm{L}) \\
\pm \mathrm{SD}(\mathrm{g} / \mathrm{L})\end{array}$ & $\begin{array}{l}\text { Ethanol } \\
\text { concentration } \\
\text { found } \\
(\% \mathrm{~V} / \mathrm{V})\end{array}$ & $\begin{array}{l}\text { Ethanol } \\
\text { concentration found } \\
\text { (g/L) } \\
\pm \mathrm{SD}(\mathrm{g} / \mathrm{L})\end{array}$ \\
\hline $\begin{array}{l}\text { “Moretti” } \\
\text { Beer }\end{array}$ & 4.6 & 4.0 & $31.9 \pm 0.5$ & 4.3 & $33.7 \pm 0.4$ & 4.8 & $38.3 \pm 3.0$ \\
\hline $\begin{array}{l}\text { “Tuborg” premium } \\
\text { green Beer }\end{array}$ & 5 & 4.3 & $34.1 \pm 2.4$ & 5.9 & $46.4 \pm 1.3$ & 5.4 & $42.6 \pm 7.1$ \\
\hline “Wührer" Beer & 4.7 & 4.1 & $32.5 \pm 0.6$ & 5.7 & $44.8 \pm 0.5$ & 4.8 & $37.8 \pm 7.5$ \\
\hline $\begin{array}{l}\text { “Conad" White } \\
\text { Wine }\end{array}$ & 11 & 11.8 & $93.1 \pm 2.3$ & 10.7 & $84.7 \pm 3.0$ & 10.9 & $85.9 .0 \pm 5.7$ \\
\hline $\begin{array}{l}\text { "Vernaccia" } \\
\text { White Wine }\end{array}$ & 12.25 & 12.6 & $99.6 \pm 2.9$ & 12.3 & $96.8 \pm 4.1$ & 12.0 & $95.0 \pm 8.1$ \\
\hline "Conad" Red Wine & 11.5 & 10.7 & $84.5 \pm 2.2$ & 12.3 & $97.4 \pm 3.6$ & 11.5 & $91.1 \pm 8.5$ \\
\hline Farmer Red Wine & Not declared & 11.2 & $88.3 \pm 3.6$ & 10.1 & $80.1 \pm 3.8$ & 10.7 & $84.4 \pm 8.0$ \\
\hline
\end{tabular}

1 Declared by producer firm.

Table 5

F-test: comparison among precisions, two sided ( $p=95 \%)$.

\begin{tabular}{|c|c|c|c|c|c|c|c|c|c|c|c|}
\hline \multirow{3}{*}{$\begin{array}{l}\text { Catalase biosensor } \\
\mathrm{SD}(\mathrm{g} / \mathrm{L})\end{array}$} & \multirow{3}{*}{$\begin{array}{l}\text { Alcohol oxidase biosensor } \\
\text { SD }(g / L)\end{array}$} & \multirow{3}{*}{$\begin{array}{l}\text { Fuel cell SD } \\
(\mathrm{g} / \mathrm{L})\end{array}$} & \multirow{3}{*}{$\begin{array}{l}\text { Catalase vs. alcohol } \\
\text { oxidase } \\
\text { (a) } \\
\text { F-exp. }\end{array}$} & \multirow{3}{*}{$\begin{array}{l}\text { Catalase vs. fuel } \\
\text { cell } \\
\text { (b) } \\
\text { F-exp. }\end{array}$} & \multirow{3}{*}{$\begin{array}{l}\text { Alcohol oxidase vs. } \\
\text { fuel cell } \\
\text { (c) } \\
\text { F-exp. }\end{array}$} & \multicolumn{6}{|c|}{ Result of the test } \\
\hline & & & & & & \multicolumn{3}{|c|}{ F-cr. $(p=95 \%)$} & \multirow[t]{2}{*}{ (a) } & \multirow[t]{2}{*}{ (b) } & \multirow[t]{2}{*}{ (a) } \\
\hline & & & & & & (a) & (b) & (c) & & & \\
\hline 0.5 & 0.4 & 3.0 & 1.56 & 36.0 & 56.3 & 9.60 & 10.6 & 10.6 & N.S. & S. & S. \\
\hline 2.4 & 1.3 & 4.0 & 3.41 & 2.78 & 9.47 & 9.60 & 10.6 & 10.6 & N.S. & N.S. & N.S. \\
\hline 0.6 & 0.5 & 7.5 & 1.44 & 156.3 & 225 & 9.60 & 10.6 & 10.6 & N.S. & S. & S. \\
\hline 2.3 & 3 & 5.7 & 1.70 & 6.14 & 3.61 & 9.60 & 10.6 & 10.6 & N.S. & N.S. & N.S. \\
\hline 2.9 & 4.1 & 8.1 & 2.00 & 7.80 & 3.90 & 9.60 & 10.6 & 10.6 & N.S. & N.S. & N.S. \\
\hline 2.2 & 3.6 & 6.9 & 2.68 & 9.84 & 3.67 & 9.60 & 10.6 & 10.6 & N.S. & N.S. & N.S. \\
\hline 3.6 & 3.8 & 8.0 & 1.11 & 4.94 & 4.43 & 9.60 & 10.6 & 10.6 & N.S. & N.S. & N.S. ${ }^{1}$ \\
\hline
\end{tabular}

Fexp. = F-experimental; Fcr. = F-critical; N.S. = Not Significant; S. = Significant.

However, a certain contribution to the loss of linearity, at the concentrations more high, it may, at least in part, be attributed to the development of $\mathrm{CO}_{2}$, which can begin accumulate at the anode, for high alcohol concentrations. 
Table 6

Paired t-test, two sided, $v=5,(\mathrm{p}=95 \%)$.

\begin{tabular}{|c|c|c|c|c|c|c|c|c|c|}
\hline \multirow{2}{*}{$\begin{array}{l}\text { Ethanol }(\mathrm{g} / \mathrm{L}) \text { reported } \\
\text { by manufacturer } \\
\text { (nominal value) } \\
\text { (a) }\end{array}$} & \multicolumn{3}{|c|}{ Ethanol $(\mathrm{g} / \mathrm{L})$ found } & \multicolumn{3}{|c|}{$\begin{array}{l}\text { Differences among nominal } \\
\text { value and ethanol found }(\mathrm{g} / \mathrm{L})\end{array}$} & \multicolumn{3}{|l|}{ t-experimental } \\
\hline & $\begin{array}{l}\text { By Catalase } \\
\text { sensor } \\
\text { (b) }\end{array}$ & $\begin{array}{l}\text { By Alcohol } \\
\text { oxidase sensor } \\
\text { (c) }\end{array}$ & $\begin{array}{l}\text { By Fuel cell } \\
\text { (d) }\end{array}$ & $\Delta=(\mathrm{b}-\mathrm{a})$ & $\Delta=(\mathrm{c}-\mathrm{a})$ & $\Delta=(\mathrm{d}-\mathrm{a})$ & $\begin{array}{l}\text { (b) } \\
-0.8881\end{array}$ & $\begin{array}{l}\text { (c) } \\
1.421\end{array}$ & $\begin{array}{l}\text { (d) } \\
0.8476\end{array}$ \\
\hline 36.29 & 31.9 & 33.7 & 38.3 & -4.39 & -2.59 & 2.01 & t-critical & & \\
\hline 39.45 & 34.1 & 46.4 & 42.6 & -5.35 & 6.95 & 3.15 & 2.571 & 2.571 & 2.571 \\
\hline 37.08 & 32.5 & 44.8 & 37.8 & -4.58 & 7.72 & 0.717 & $\mid$ t-exp. $\mid<$ t-cr. & $\mid$ t-exp. $\mid<$ t-cr. & $\mid \mathrm{t}$-exp. $\mid<\mathrm{t}$-cr. \\
\hline 86.79 & 93.1 & 84.7 & 85.9 & 6.31 & -2.09 & -0.890 & Results of t-test & & \\
\hline 96.65 & 99.6 & 96.8 & 95.0 & 2.95 & 0.148 & -1.65 & $\begin{array}{l}\text { Not } \\
\text { significant }\end{array}$ & $\begin{array}{l}\text { Not } \\
\text { significant }\end{array}$ & $\begin{array}{l}\text { Not } \\
\text { significant }\end{array}$ \\
\hline \multirow[t]{2}{*}{90.73} & 84.5 & 97.4 & 91.1 & -6.24 & 6.67 & 0.365 & & & \\
\hline & & & & $\begin{array}{l}\Delta_{\mathrm{m}} \pm \mathrm{SD} \\
-1.88 \pm 5.20\end{array}$ & $\begin{array}{l}\Delta_{\mathrm{m}} \pm \mathrm{SD} \\
2.80 \pm 4.82\end{array}$ & $\begin{array}{l}\Delta_{\mathrm{m}} \pm \mathrm{SD} \\
0.616 \pm 1.78\end{array}$ & & & \\
\hline
\end{tabular}

Table 7

Correlation of straight line equations among three methods for ethanol determinations.

\begin{tabular}{|c|c|c|}
\hline \multirow[t]{3}{*}{$\begin{array}{l}\text { Ethanol concentration found by catalase biosensor } v s \text {. ethanol concentration found using alcohol oxidase } \\
\text { biosensor }\end{array}$} & $\begin{array}{l}\text { Correlation's } \\
\text { equation }\end{array}$ & $\mathrm{Y}=1.13( \pm 0.15) \mathrm{X}-12.1( \pm 11.0)$ \\
\hline & $\mathrm{R}^{2}$ & 0.9194 \\
\hline & Confidence intervals & $99 \%$ \\
\hline \multirow[t]{3}{*}{ Ethanol concentration found by catalase biosensor vs. ethanol concentration found using fuel cell } & $\begin{array}{l}\text { Correlation's } \\
\text { equation }\end{array}$ & $\begin{array}{l}Y=1.17( \pm 0.08) X-13.12 \\
( \pm 5.66)\end{array}$ \\
\hline & $\mathrm{R}^{2}$ & 0.9781 \\
\hline & Confidence intervals & $99 \%$ \\
\hline \multirow[t]{3}{*}{ Ethanol concentration found by alcohol oxidase biosensor vs. ethanol concentration found using fuel cell } & $\begin{array}{l}\text { Correlation's } \\
\text { equation }\end{array}$ & $\begin{array}{l}Y=0.98( \pm 0.08) X+2.33 \\
( \pm 5.74)\end{array}$ \\
\hline & $\mathrm{R}^{2}$ & 0.9685 \\
\hline & Confidence intervals & $99 \%$ \\
\hline
\end{tabular}

Lastly, sensor lifetime is in all cases at least greater than 23 months (Table 1). It is clear however that this lifetime was estimated by us in the same general way in which it usually operating to determine the lifetime of electrochemical sensors or biosensors; that is the cell has not been used in continuous the whole day and every day during these months, as is sometimes done when one wants to evaluate the characteristics of maximum energy output of a device of this type. In fact, in our case the cell has been used only 3-4 days a week and performing no more than about three daily measurements; thereby requiring to fuel cell, used for analytical purposes, about the same performances that are tipically required to a common electrochemical sensors or biosensors. This a discontinuous way to use the fuel cell and the time, very limited, which is need to make a measurement, using the potentiostatic format, are certainly the main reasons, not only the durability of the fuel cell, but also of the fact, we have experimentally proved, that if the calibration straight line is repeated after a few weeks, the values of the slope and the intercept, which are obtained for the corresponding equation, vary only within the limits of \pm SD reported for the equations shown in Fig. 7(a) and (b): this in practice attests the good reproducibility of measures during the lifetime of the fuel cell, reported above. Lastly, if it is compared (see Table 3 ) the main analytical data of the fuel cell (using the potentiostatic format) with those of two conventional enzymatic biosensors, it can be observe as the LOD of the latter, especially for ethanol, is significantly lower than that of the fuel cell and the linearity range usually larger. Nevertheless, as can be seen in the same table, by using three sensors, with the same procedures and the same frequency of measurement described above, the lifetime of the fuel cell is extremely longer. Moreover, the LOD and linearity range of the fuel cell, they are also more than enough to take safety measurements in real samples, such as those analyzed in this research, as evidenced by the data shown in Tables 4, 5 and 6.

The life times very different, of course, also affects the cost of analysis; in fact, if initially the purchase costs of a small catalytic fuel cell and that a good amperometric electrode for oxygen (Clarktype), to which must be added the cost of the commercial enzyme alcohol oxidase, or catalase, are approximately of the same order, it is nevertheless clear that if the conventional enzymatic sensors must operate for two-three months in which case the enzyme must be renewed more times (at least weekly, or monthly, depending on the enzyme) (see Table 3), this increases the overall cost of the analysis, if these conventional biosensors are used, when compared by the cost of fuel cell, which, however, for a similar period of time, has no problem, except that of a correct handling and maintenance.

Concerning the applications to real samples containing ethanol (commercial wines and beers), the agreement with the nominal values, reported by the producer, may generally be accepted as very good and, except in one case, better than the agreement obtained using the other two conventional enzymatic-amperometric methods and the nominal values themselves. However, also the agreement between the values obtained using the fuel cell and the other two conventional biosensor methods, the latter already extensively tested both by us [22,23] and other researchers [28$30]$, is more than satisfactory, as is shown by the correlation curves and $\mathrm{R}^{2}$ coefficients set out in Table 7 . Lastly, also the results of the statistical tests, set out in Tables 5 and 6, are more than satisfactory. Indeed the two-sided test shows that the differences between the values found in the three different t-tests are always non significant, while the F-test shows that the comparison with the precision values for the three methods used is significant in only 4 cases out of 21 . Selectivity is higher for methanol, but the fuel cell 
sensor shows a good response also for ethanol (Table 2). Moreover the response decreases if the chain length or complexity of the alcohol increases (see the same Table).

\section{Conclusions}

We can conclude that, a small fuel cell of the type we tested, can be satisfactorily used for analytical purposes, both using the (RC) potentiostatic format or the OCV kinetic format. In fact, the advantage of kinetic measurement (using the OCV format) consists of the more short measurement time, compared with the classical open circuit voltage format; anyway measurement times are further reduced on going from measures in OCV- kinetic format to measures in the potentiostatic format, i.e. recording the (SC) supplied current by the cell; therefore the latter is the best format for analytical measurement purposes. Lastly, the results obtained from the analysis of real samples, consisting of different commercial alcoholic beverages, are particularly significant in our view as (for the first time it would seem) they afford the possibility of performing effective analytical tests on real samples using a simple direct small methanol fuel cell, even of the commercial type, therefore of very limited cost and operating mostly at room temperature, in batch mode, for very long time, at least greater than two - three months, during which it is able to provide a response lying within the confidence limits of method.

Furthermore it proved not to be subject to any particular interference even in the applications to ethanol analysis in real samples. At least when the measure is performed in the potentiostatic format, measurement time, although not very short, is found to be no longer for example than that of classical immunosensor methods [31,32]. It could certainly be further reduced by working at higher temperatures, for instance at $60^{\circ} \mathrm{C}$ $[10,12]$. In this case however it would be necessary employ a cumbersome and unpractical thermostatic equipment. However, it would perhaps be possible to further reduce this time by using an oxyreductive enzyme. Preliminary tests in this direction performed by us have afforded interesting results. These will be discussed in a specific future publication.

\section{Acknowledgements}

This work was funded by "La Sapienza" University of Rome, "Ateneo and University Projects". The authors are indebted to the Prof. Fausto Croce (Department of Pharmacy, "G.d'Annunzio" University, Chieti, Italy) for his suggestions concerning DMFC and to FUEL CELL STORE www.fuelcellstore.com (College Station, TX, USA) and H-TEC EDUCATION GmbH (Luebeck, Germany) for the technical assistance.

\section{references}

[1] E.G.S. Parsons, Fuel Cell Handbook, Fifth Edition, U.S. Department of Energy, Morgantown, West Virginia, 2000 26507-0880.

[2] L.J.M. Blomen, M.N. Mugerwa, Fuel Cell Systems, Springer, US, 1993.

[3] J.O.M. Bokris, S. Srinivasan, Fuel cells: Their electrochemistry, AIChE Journal, McGraw-Hill, New York, 1969, pp. 512-702 659 pages., 1969.

[4] S. Srinivasan, B.B. Davé, K.A. Murugesamoorthi, A. Parthasarathy, A.J. Appleby, Overview of Fuel Cell Technology, in: L.M.J. Blomen, M. Mugerwa (Eds.), Fue Cell Systems, Springer, US, 1993, pp. 37-72.

[5] S. Arora, G. Pastorella, B. Byrne, E. Marsili, R. O’Kennedy, Microbial cells and biosensing: a dual approach-exploiting antibodies and microbial cells as analytical/power systems, Reviews inPharmaceutical and Biomedical Analysis, Bentham Science Publishers, Sharjah, UAE, 2010, pp. 63-75.

[6] L. Carrette, K.A. Friedrich, U. Stimming, Fuel cells: principles, types, fuels, and applications, Chemphyschem 1 (December) (2000) 162-193.

[7] D. Hart. (2014, 20/05/2015). Fuelcell: introduction. Available: http://www.esources.com/fuelcell-intro.htm.

[8] F. Barbir, PEM fuel cells: theory and practice, 2nd Edition, Elsevier/Academic Press, Burlington, 2012.

[9] V. Mehta, J.S. Cooper, Review and analysis of PEM fuel cell design and manufacturing, Journal of Power Sources 114 (2003) 32-53.

[10] H. Liu, C. Song, L. Zhang, J. Zhang, H. Wang, D.P. Wilkinson, A review of anode catalysis in the direct methanol fuel cell, Journal of Power Sources 155 (2006) 95-110.

[11] A. Wasmus, Küver, Methanol oxidation and direct methanol fuel cells: a selective review, Journal of Electroanalytical Chemistry 461 (1999) 14-31.

[12] A. Hamnett, Mechanism and electrocatalysis in the direct methanol fuel cell, Catalysis Today 38 (1997) 445-457 11/29/1997.

[13] S. Almheiri, H. Liu, Separate measurement of current density under land and channel in Direct Methanol Fuel Cells, Journal of Power Sources 246 (2014) 899-905 1/15/2014.

[14] P. Joghee, S. Pylypenko, K. Wood, A. Corpuz, G. Bender, H.N. Dinh, et al., Improvement in direct methanol fuel cell performance by treating the anode at high anodic potential, Journal of Power Sources 245 (2016) 37-47 1/1/2014.

[15] N. Fujiwara, Z. Siroma, S.-i. Yamazaki, T. Ioroi, H. Senoh, K. Yasuda, Direct ethanol fuel cells using an anion exchange membrane, Journal of Power Sources 185 (2006) 621-626 12/1/2008.

[16] S.A.C. Barton, B.L. Murach, T.F. Fuller, A.C. West, A methanol sensor for portable direct methanol fuel cells, Journal of the electrochemical society 145 (1998) 3783-3788.

[17] S.R. Narayanan, T.I. Valdez, W. Chun, Design and operation of an electrochemical methanol concentration sensor for direct methanol fuel cell systems, Electrochemical and Solid-State Letters 3 (2000) 117-120.

[18] D. Sparks, C. Laroche, N. Tran, D. Goetzinger, N. Najafi, K. Kawaguchi, et al., A new methanol concentration microsensor for improved DMFC performance, Fuel Cell Summit (2005).

[19] W. Sun, G. Sun, W. Yang, S. Yang, Q. Xin, A methanol concentration sensor using twin membrane electrode assemblies operated in pulsed mode for DMFC, Journal of Power Sources 162 (2006) 1115-1121.

[20] G. Davis, H.A.O. Hill, W.J. Aston, I. John Higgins, A.P.F. Turner, Bioelectrochemical fuel cell and sensor based on a quinoprotein, alcohol dehydrogenase, Enzyme and Microbial Technology 5 (1983) 383-388 9//1983.

[21] H. Zhao, J. Shen, J. Zhang, H. Wang, D.P. Wilkinson, C.E. Gu, Liquid methanol concentration sensors for direct methanol fuel cells, Journal of Power Sources 159 (2006) 626-636 9/13/2006.

[22] R. Angeloni, M. Tomassetti, M. Castrucci, L. Campanella, Ethanol Determination in Alcoholic Beverages Using Two Different Amperometric Enzyme Sensors, Current Analytical Chemistry 11 (2015) 56-67 //2015.

[23] L. Campanella, G.S. Capesciotti, T. Gatta, M. Tomassetti, An innovative organic phase enzyme electrode (OPEE) for the determination of ethanol in leadless petrols, Sensors and Actuators B: Chemical 147 (2010) 78-86 5/18/2010.

[24] T. Kumagai, T. Horiba, T. Kamo, S. Takeuchi, K. Iwamoto, K. Kitami, K. Tamura, Google Patents, US 4810597 A, 1989.

[25] P. Pei, H. Xu, X. Zeng, H. Zha, M. Song, Use of galvanostatic charge method as a membrane electrode assembly diagnostic tool in a fuel cell stack, Journal of Power Sources 245 (2014) 175-182.

[26] J.B. Benziger, M.B. Satterfield, W.H.J. Hogarth, J.P. Nehlsen, I.G. Kevrekidis, The power performance curve for engineering analysis of fuel cells, Journal of power sources 155 (2006) 272-285.

[27] M. Isa, B. Ismail, C.M. Hadzer, I. Daut, F.A. Bakar, Characteristic Curve of a Fuel Cell, American Journal of Applied Sciences 3 (2006) 2134-2135.

[28] A.M. Azevedo, D.M.F. Prazeres, J.M.S. Cabral, L.P. Fonseca, Ethanol biosensors based on alcohol oxidase, Biosensors and Bioelectronics 21 (2005) 235-247 8 / $15 / 2005$.

[29] T.B. Goriushkina, A.P. Orlova, G.M. Veryk, A.P. Soldatkin, S.V. Dzyadevych, The procedure of ethanol determination in wine by enzyme amperometric biosensor, Biopolym. Cell. 25 (2009) 11.

[30] E. Akyilmaz, Dinçkaya, Development of a catalase based biosensor for alcohol determination in beer samples, Talanta 61 (Oct 2003) 113-118.

[31] G. Merola, E. Martini, M. Tomassetti, L. Campanella, Simple and suitable immunosensor for $\beta$-lactam antibiotics analysis in real matrixes: Milk, serum, urine, Journal of Pharmaceutical and Biomedical Analysis 106 (2015) 186-196 $3 / 15 / 2015$.

[32] L. Campanella, S. Eremin, D. Lelo, E. Martini, M. Tomassetti, Reliable new immunosensor for atrazine pesticide analysis, Sensors and Actuators B: Chemical 156 (2011) 50-62 8/10/2011. 